\title{
Cytotoxic and Genotoxic Activity of Turkish Pale Liverwort (Chiloscyphus polyanthos (L.) Corda) Against Human Periferal Blood Lymphocytes
}

\author{
Recep KARA $^{1 *}$, Cansu AYDIN ${ }^{2}$ iD, Songül BUDAK DİLER ${ }^{2}$ iD \\ ${ }^{l}$ Department of Biology, Faculty of Science and Letters, Nevsehir Hacı Bektas Veli University, Nevşehir, \\ TURKEY \\ ${ }^{2}$ Department of Biotecnology, Faculty of Science and Letters, Nigde Omer Halisdemir University, Niğde,
} TURKEY

\begin{abstract}
\begin{tabular}{lll}
\hline Received: 11.10.2019 & Revised: 28.10.2019 & Accepted: 13.01.2020
\end{tabular}
Abstract

Pale Liverwort-Chiloscyphus polyanthos is one of the most common aquatic liverworts that growing in or near the watering streams and lakes. It typically formed extensive matting appearance in the water or on the boulders in the water. In this study, Chiloscyphus polyanthos collected from the Erciyes Mountain were extracted using ethyl acetate, methanol, and water-methanol solvents. Cytotoxic and genotoxic effects of extracts against human peripheral blood lymphocytes were investigated. The genotoxic activity was determined by using the Chromosome Aberration Test. The cytotoxic activities of the extracts were determined by the Mitotic index (MI). The results showed that the extracts had cytotoxic effect and not genotoxic effect. According to this result, we estimate that Chiloscyphus polyanthos can be used as medicinal plant.
\end{abstract}

Keywords: Hepatophyta, Medicinal Plants, Chromosome Aberrations, Sister Chromatid Exchange.

\section{Türk Soluk Ciğgerotu (Chiloscyphus polyanthos (L.) Corda)'nun İnsan Periferal Kan Lenfositlerine Karşı Sitotoksik ve Genotoksik Aktivitesi}

$\ddot{O} \mathbf{z}$

Chiloscyphus polyanthos, göllerde ve akarsularda su içinde veya su kenarında yetişen en yaygın akuatik ciğerotlarından biridir. Tipik olarak, su içerisinde veya su içindeki kayaların üzerinde geniş paspas görünümü oluşturur. Bu çalışmada, Erciyes Dağı'ndan toplanan Chiloscyphus polyanthos, etil asetat, metanol ve su-metanol çözücüleri kullanılarak ekstre edildi. Ekstraktların insan periferal kan lenfositlerine karş1 sitotoksik ve genotoksik etkileri araştırıldı. Genotoksik aktivite, Kromozom Aberrasyon Testi kullanılarak belirlendi. Ekstraktların sitotoksik aktiviteleri Mitotik indeks (MI) ile belirlendi. Sonuçlar ekstraktların sitotoksik etkiye sahip olduğunu, genotoksik etkiye sahip olmadığını gösterdi. Bu sonuca göre Chiloscyphus polyanthos'un tıbbi bitki olarak kullanılabileceğini tahmin etmekteyiz.

Anahtar kelimeler: Hepatophyta, Tıbbi Bitkiler, Kromozom Aberasyonu, Kardeş Kromatid Değişimi.

\footnotetext{
* Corresponding author: recepkara@ nevsehir.edu.tr

(C) 2020 All rights reserved / Tüm haklarl saklıdır.

To cite this article: Kara R. Aydin C. Budak Diler S. 2020. Cytotoxic and Genotoxic Activity of Turkish Pale Liverwort (Chiloscyphus polyanthos (L.) Corda) Against Human Periferal Blood Lymphocytes. Anatolian Bryology. 6:1, 1-7.

(c) (1) (2) This work is licensed under a Creative Commons Attribution-Non Commercial 4.0 International License.
} 


\section{Introduction}

Bryophytes which are known as the oldest land plants, present antimicrobial activity as they contain many secondary metabolites, so they are relatively free from attack by parasitic microorganisms (Suhalka, 2016). The bryophytes have been investigated pharmaceutically for active biomolecules. Several constituents with therapeutic potential have been isolated, characterized and investigated for anti-bacterial, anti-fungal, anti-viral, anti-oxidative, antiinflammatory, anti-tumoral and anti-cancer activity (Saxena and Harinder, 2004; Çolak et al., 2011; Dey and De, 2012; Asakawa et al., 2013a; Chandra et al., 2017). The bryophytes are placed taxonomically between algae and pteridophytes; there are about 24000 species in the world. They are further divided into three phyla, Bryophyta (mosses 14,000 species), Marchantiophyta (liverworts 6,000 species), and Anthocerotophyta (hornworts 300 species) [Alam, 2012; Asakawa et al., 2013b].

Crude extracts and isolated compounds from bryophytes were found to possess potent cytotoxic properties. Different types of terpenoids and bibenzyls have been reported among the most potent cytotoxic compounds (Dey and Mukherjee, 2015). Many hepatics and mosses have been investigated for cytotoxic activities (Perry et al., 1996; Burgess et al., 2000; Komala et al., 2010; Asakawa et al., 2013b; Yağlıoglu et al., 2017) but there is no information about the genotoxic and cytotoxic activities of Chiloscyphus polyanthos in the literature. It is a liverwort that belongs to the Lophocoleaceae family. This is a medium-sized leafy liverwort and has a translucent leaf. The upper side of the leaf is pale green and thus known by the name 'Pale liverwort' (Fig. 1). This plant grows mainly on rocks in streams, flushes and wet ground, and could almost be considered an aquatic species (Atherton et al., 2010) The liverwort has been investigated phytochemically, and several eudesmane sesquiterpenes have been obtained from this species (Xie et al., 2011). Chiloscyphus spp. are well-known to contain various chiloscyphane sesquiterpenoids (Toyota et al., 1999). The present study aims to evaluate the cytotoxic and genotoxic activity of the fractionated extract as well as isolated compounds of $C$. polyanthos against human peripheral blood lymphocytes.
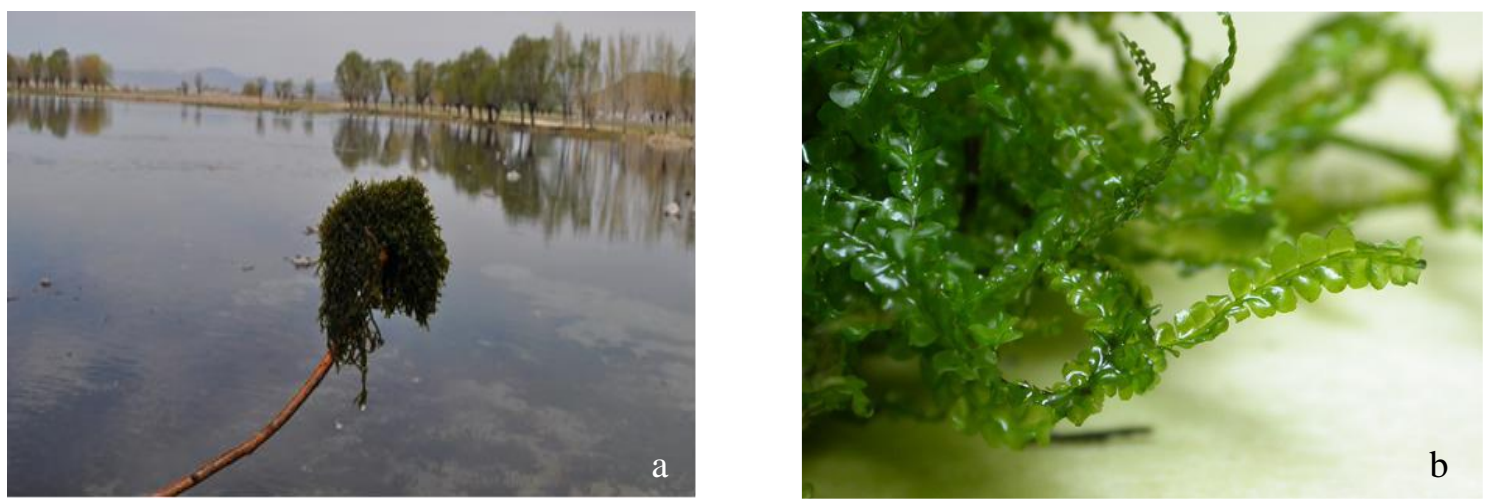

Figure 1. Chilochyphus polyanthos habitat(a) and close-up (b)

\section{Materials and Methods}

In this study, peripheral blood samples that belong to two male and two female donors who are ranged between the age of 20-24 and have never consumed alcohol, drug or cigars, were used to determine cytotoxic and genotoxic activity. The test material, $C$. polyanthos liverwort species extract of Marchantiophyta (liverworts) were used at the concentrations of 2.5, 5 and $10 \mu \mathrm{g} / \mathrm{mL}$. Chromosome Aberration Test was used to detect chromosomal abnormalities. The preparations were treated for 24 and 48 hours and made permanent stained with giemsa stain solution and covered with entellan. The photographs in this study were taken using OLYMPUS CX31 binocular light microscope (Fig.2-Fig.7).

Mitotic index (MI) was calculated to determine the cytotoxic effect of $C$. polyanthos (Rencüzogulları et al., 2006). 3000 cells were counted for each slide during the examination and the percentage of dividing cells has been identified. A total of 100 cells (400 cells of four people) were examined to determine the genotoxic effect of $C$. polyanthos and CAs is determined. During the examination, structural CAs data such as chromatid break, chromosome break, the fragments, dicentric chromosome observed in cells were recorded (Table 1-2), (Figure 8-11). Moreover, active compounds in 
the extract were determined using gas chromatography - mass spectrometry (GC / MS) techniques.

The necessary permission was received from the Erciyes University Clinical Research Ethics Committee (2014/292). The samples of liverworts were collected from Erciyes Mountain (Soysallı village - Büyüleyen lake Develi /Kayseri) on 04.04.2014.

\section{Findings}

Human peripheral blood lymphocytes were treated with 2.5, 5, and $10 \mu \mathrm{g} / \mathrm{mL}$ concentrations of Chiloschyphus polyanthos $(\mathrm{Cp})$ plant extract, with two different treatment periods, 24 and 48 hours. According to ANOVA analysis, it was not found that "CA" data were significant (Figure 8-9). There was no statistically significant increase in cell percent carrying "CA" in human peripheral blood lymphocytes treated with $\mathrm{Cp}$ extracts for both 48 hours and 24 hours (Table 1).

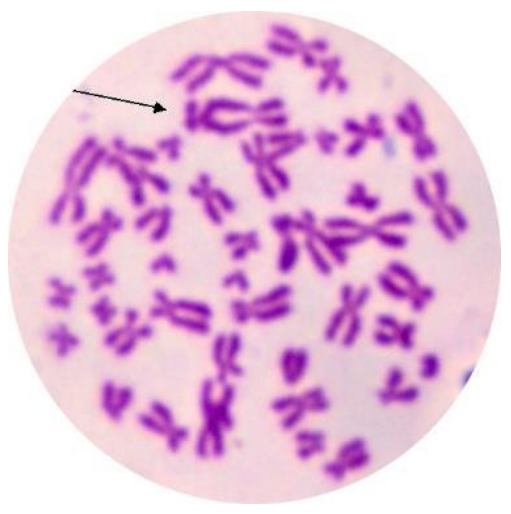

Figure 2. Dicentric chromosome

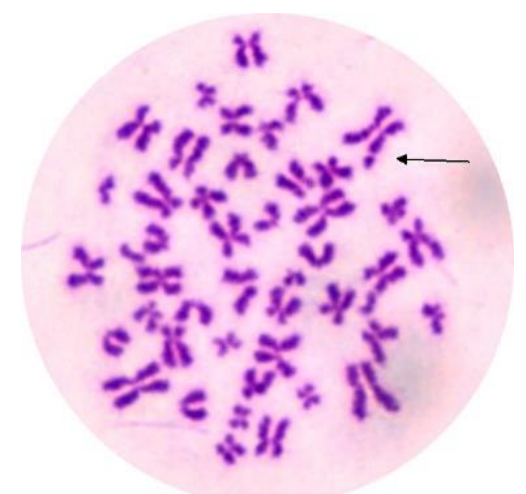

Figure 4. Chromatid break
Mitotic Index (MI) shows the effect of Cp plant extract on mitosis. Cp plant extract was found to show the cytotoxic effect at both 24 hour and 48 hour treatment periods and all concentrations $(2.5,5,10 \mu \mathrm{g} / \mathrm{mL})$ according to statistical analysis (Figure 10-11). It was found that Cp plant extract significantly reduced $\mathrm{MI}$ at 48 and 24 hours of treatment at all concentrations (2.5, $5,10 \mu \mathrm{g} / \mathrm{mL}$ ) compared to control and alcohol control. However, no concentration was found to decrease positive control. The difference between decreases in concentrations compared to control groups is remarkable (Table 2).

According to the gas chromatography techniques (GC/MS), the active compounds in the extract were determined to Alpha Selinene, Beta Selinene, Neophytadiene, hexadecen-1-ol, 3,7,11,15-tetramethyl, Octadecanoic acid, ethyl ester, Hexadecanicacid, 2,3-dihydroxypropyl ester, Octadecanoic acid,2-3-dihydroxypropyl ester and Cholest-5-en-3-ol (3. Beta). Some photos of chromosome damage taken in this study are presented below.

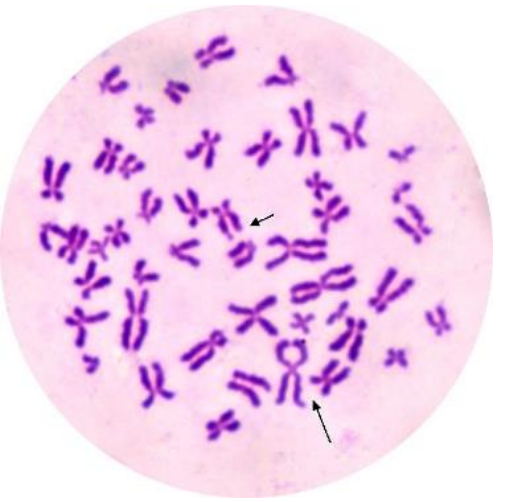

Figure 3. Sister union and Chromatid break

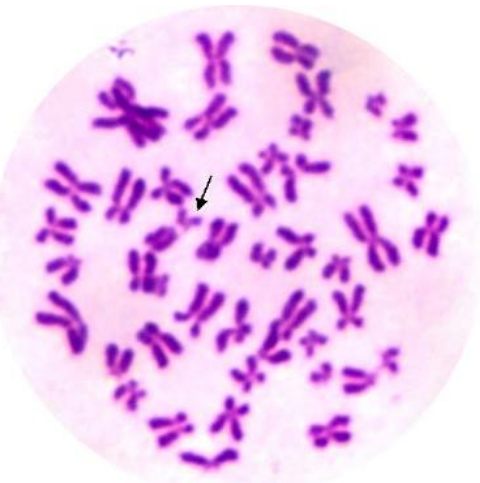

Figure 5. Chromatid break 


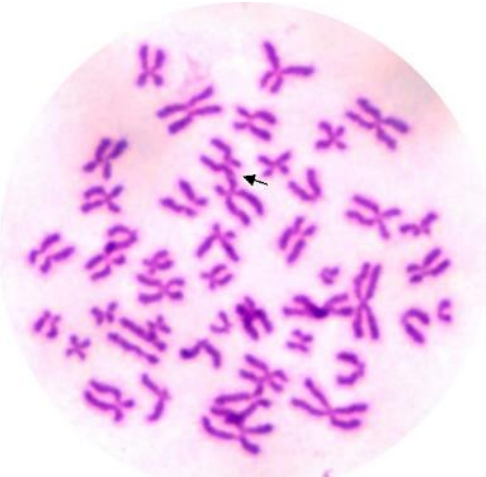

Figure 6. Monocentric chromosome

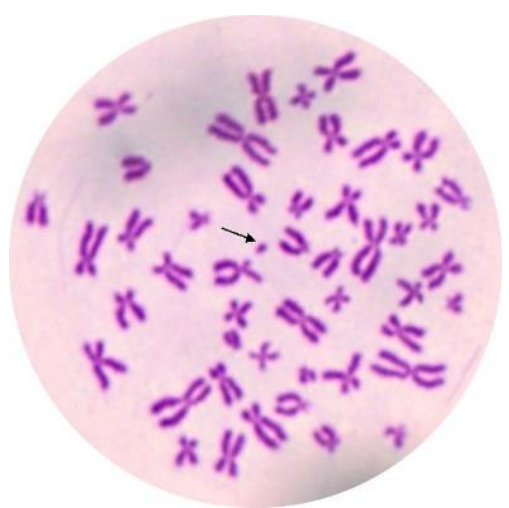

Figure 7. Fragment

Table 1. Chromosome aberrations in cultured human lymphocytes treated with C. polyanthos extracts

\begin{tabular}{|c|c|c|c|c|c|}
\hline \multirow[b]{2}{*}{ Test substance } & \multicolumn{2}{|c|}{ Treatment } & \multicolumn{2}{|c|}{ Structural CA } & \multirow[b]{2}{*}{$\begin{array}{c}\text { Total CA } \pm \text { SE } \\
(\%)\end{array}$} \\
\hline & $\begin{array}{c}\text { periods, } \\
\mathbf{h}\end{array}$ & $\begin{array}{c}\text { concentrations } \\
(\mu \mathrm{g} / \mathrm{mL})\end{array}$ & $\begin{array}{l}\text { chromotid } \\
\text { type }\end{array}$ & $\begin{array}{c}\text { chromosome } \\
\text { type }\end{array}$ & \\
\hline Control & -- & -- & 16 & 10 & $6.50 \pm 1.19$ \\
\hline Ethanol & 24 & $10 \mu \mathrm{L} / \mathrm{mL}$ & 20 & 8 & $7.00 \pm 3.46$ \\
\hline MMC (PC) & 24 & 0.20 & 71 & 63 & $27.50 \pm 6.24 \mathrm{a}_{3} \mathrm{~b}_{3}$ \\
\hline C. polyanthos & 24 & $\begin{array}{c}2.5 \\
5 \\
10\end{array}$ & $\begin{array}{l}18 \\
22 \\
27\end{array}$ & $\begin{array}{l}16 \\
16 \\
12\end{array}$ & $\begin{array}{l}8.50 \pm 2.22 \\
9.50 \pm 1.44 \\
9.75 \pm 1.03\end{array}$ \\
\hline Ethanol & 48 & $10 \mu \mathrm{L} / \mathrm{mL}$ & 18 & 6 & $6.00 \pm 0.00$ \\
\hline $\mathrm{MMC}(\mathrm{PC})$ & 48 & 0.20 & 180 & 153 & $\begin{array}{c}54.00 \pm 13.83 \\
a_{3} b_{3} \\
\end{array}$ \\
\hline C. polyanthos & 48 & $\begin{array}{c}2.5 \\
5 \\
10 \\
\end{array}$ & $\begin{array}{l}28 \\
26 \\
27 \\
\end{array}$ & $\begin{array}{l}14 \\
19 \\
27 \\
\end{array}$ & $\begin{array}{l}10.50 \pm 2.87 \\
11.25 \pm 3.54 \\
13.50 \pm 1.94 \\
\end{array}$ \\
\hline
\end{tabular}

Notes: CA: the significance between the percentage of abnormal cell, PC: positve control SE: sister chromatid exchange a: Control; b: Alchol Control; $c$ : significant from the positive control a1b1c1: $\mathrm{P} \leq 0.05$ a2b2c2: $\mathrm{P} \leq 0.01$ a3b3c3: $\mathrm{P} \leq 0.001$

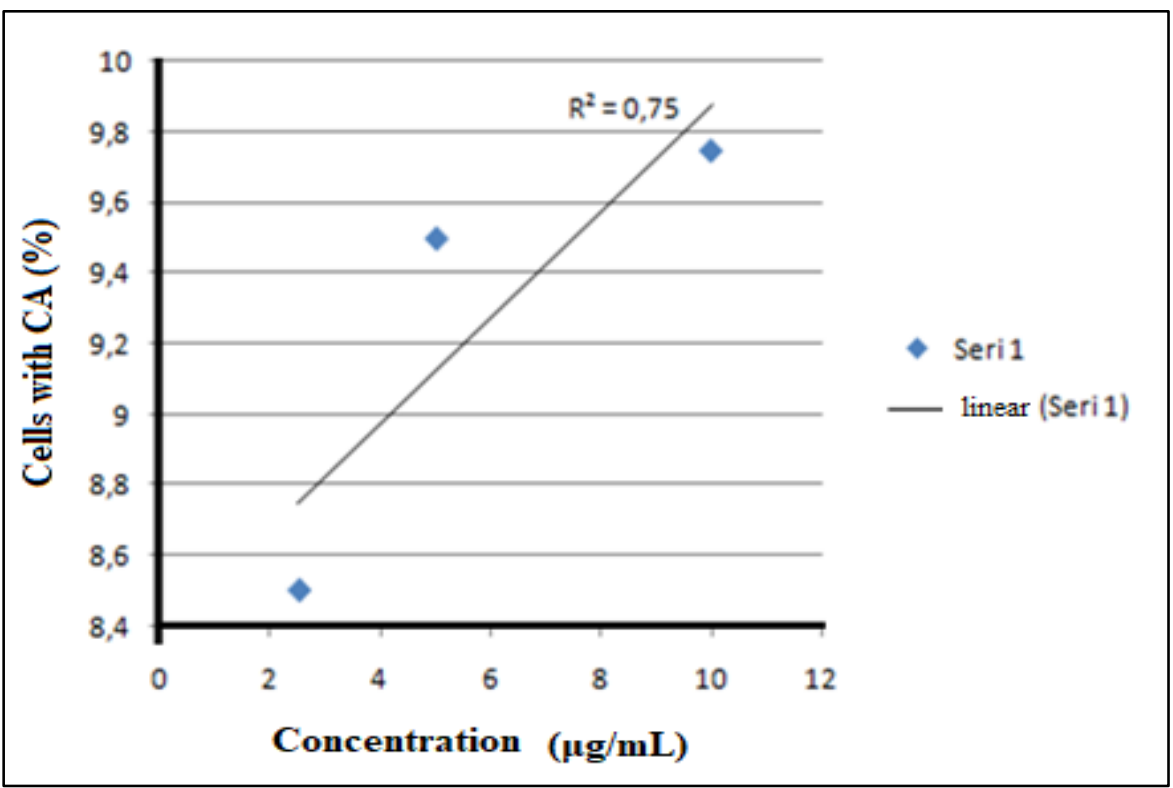

Figure 8. The linear Regression and correlation coefficient (24 h) of cells with CA 


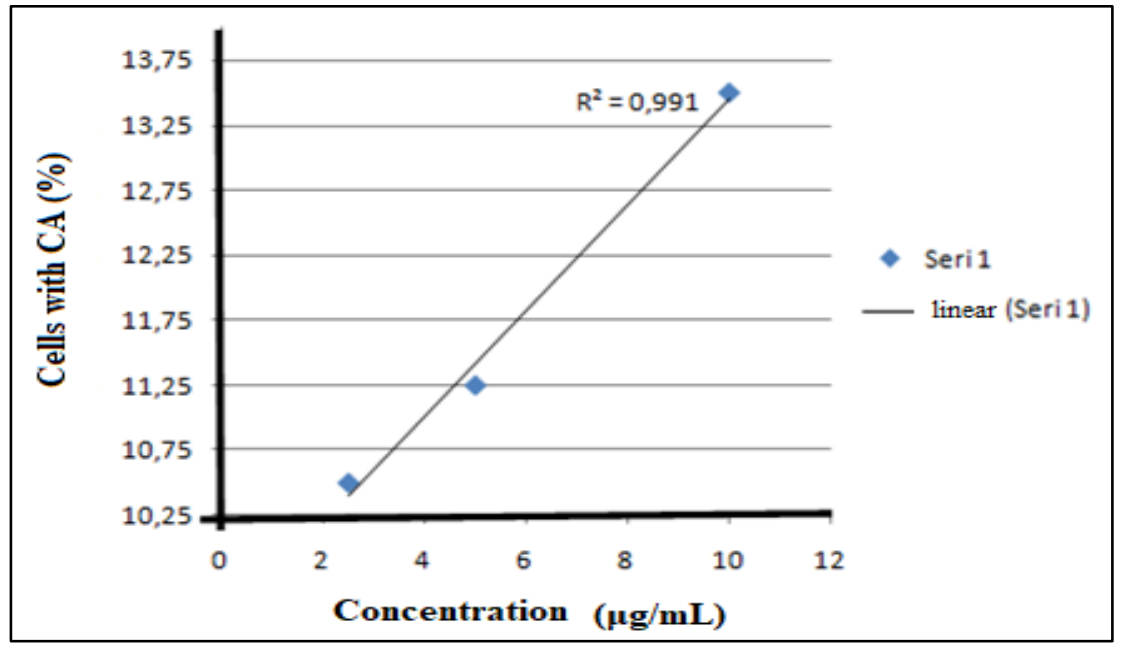

Figure 9. The linear regression and correlation coefficient ( $48 \mathrm{~h})$ of cells with CA

Table 2. Frequency of MI in cultured human lymphocytes treated with C. polyanthos extracts

\begin{tabular}{|c|c|c|c|}
\hline \multirow{2}{*}{ Test substance } & \multicolumn{2}{|c|}{ Treatment } & \multirow{2}{*}{ MI \pm SE } \\
\cline { 2 - 3 } & periods, h & $\begin{array}{c}\text { concentrations } \\
(\boldsymbol{\mu g} / \mathbf{m L})\end{array}$ & \\
\hline Control & -- & -- & $5.55 \pm 0.46$ \\
\hline Ethanol & 24 & $10 \mu \mathrm{L} / \mathrm{mL}$ & $4.74 \pm 0.30 \mathrm{c}_{3}$ \\
\hline MMC (PC) & 24 & 0.20 & $2.29 \pm 0.00 \mathrm{a}_{3} \mathrm{~b}_{3}$ \\
\hline C. polyanthos & 24 & 2.5 & $3.16 \pm 0.39 \mathrm{a}_{3} \mathrm{~b}_{3}$ \\
& & 5 & $3.05 \pm 0.27 \mathrm{a}_{3}$ \\
\hline Ethanol & 48 & 10 & $2.70 \pm 0.22 \mathrm{a}_{3} \mathrm{~b}_{3}$ \\
\hline MMC (PC) & 48 & 0.20 & $3.83 \pm 0.25 \mathrm{c}_{3}$ \\
\hline C. polyanthos & 48 & 2.5 & $2.17 \pm 0.01 \mathrm{a}_{3} \mathrm{~b}_{3}$ \\
\hline & & 5 & $2.68 \pm 0.48 \mathrm{a}_{3} \mathrm{~b}_{3}$ \\
& & 10 & $2.67 \pm 0.15 \mathrm{a}_{3} \mathrm{~b}_{3}$ \\
& & $10.45 \pm 0.18 \mathrm{a}_{3} \mathrm{~b}_{3}$ \\
\hline
\end{tabular}

Notes: MI: mitotic index, PC: positive control SE: sister chromatid Exchange a: Control; b: Alchol Control; c: significant from the positive control a1b1c1: $\mathrm{P} \leq 0.05 \mathrm{a} 2 \mathrm{~b} 2 \mathrm{c} 2$ : $\mathrm{P} \leq 0.01 \mathrm{a} 3 \mathrm{~b} 3 \mathrm{c} 3: \mathrm{P} \leq 0.001$

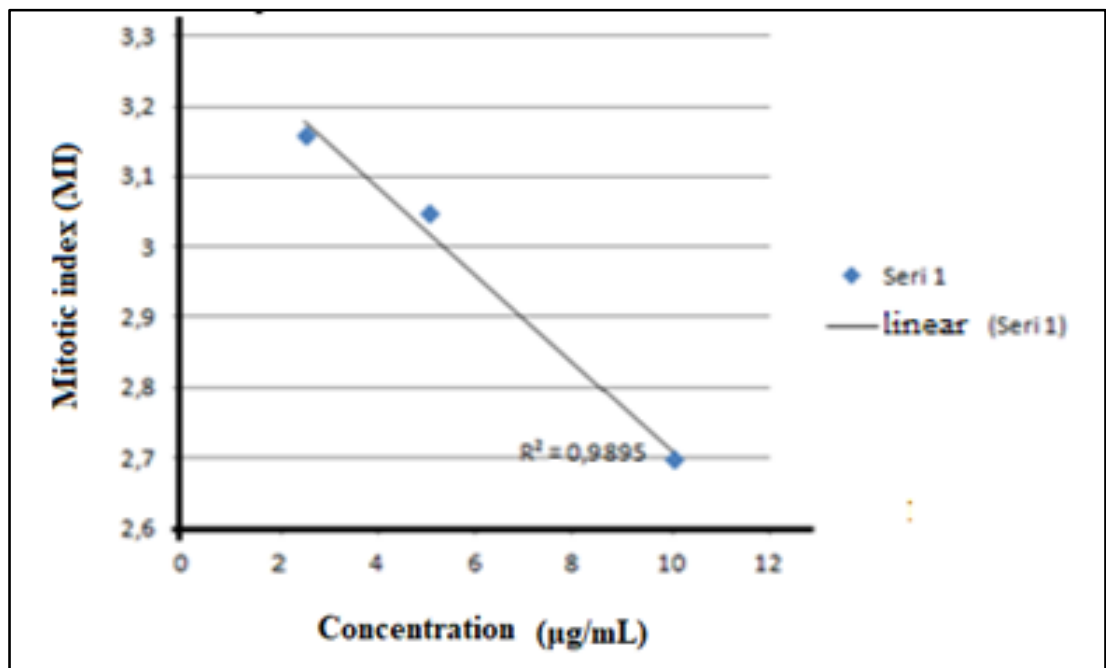

Figure 10. The linear regression and correlation coefficient $(24 \mathrm{~h})$ of mitotic index 


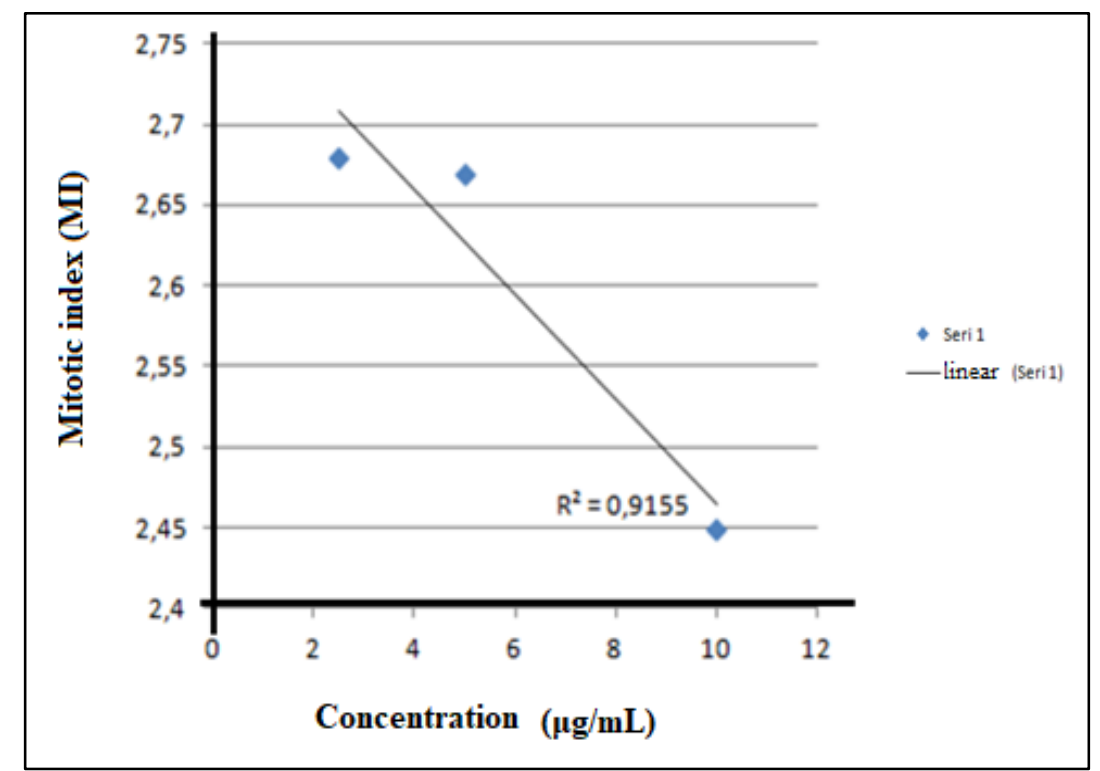

Figure 11 . The linear regression and correlation coefficient $(48 \mathrm{~h})$ of mitotic index

\section{Results and Discussion}

For statistical analysis, ONE WAY ANOVA (LSD Post Hoc Analysis-Testing) was performed by using SPSS 15.0 for Windows software. According to this analysis, no genotoxic effect of plant extract was determined. Mitotic index (MI) was determined to find out the cytotoxic effect of plant extract. MI results of the concentrations were determined important $(\mathrm{P} \leq 0,001)$ in ANOVA and LSD analysis (Table 1-2). Concentration-response relationship in MI was determined with correlation and regression analysis (Figure 8-11). According to this analysis, it was found that the plant extract reduced MI depending on dose $(24 \mathrm{hr}$; $\mathrm{R}^{2}=0.9895$, **: $\mathrm{P}=0,01$ and $48 \mathrm{hr} ; \mathrm{R}^{2}=0.9155$, **: $\mathrm{P}=0.01$ ). As a result, the plant extract was found to have no genotoxic effect on human peripheral blood lymphocytes as it has cytotoxic effect. This liverwort can be used in medicine to prevent uncontrolled proliferation of cells due to its cytotoxic effect. However, it is not known which of the compounds detected by GC / MStechniques cause cytotoxic effect. To understand this, the content of bioactive compounds needs to be investigated in detail at the molecular level.

\section{Acknowledgement}

This work is supported by the Nigde Omer Halisdemir University (Project No: YULTEP, FEB2014/28). The authors would also like to thank Assoc. Dr. İbrahim DEMIR for his help in identifying the active compounds.

\section{References}

Alam A. 2012. Some Indian Bryophytes known for their biologically active compounds. International Journal of Applied Biology and Pharmaceutical Technology. 3, 239-246.

Asakawa Y. Ludwiczuk A. Hashimoto T. 2013a. Cytotoxic and antiviral compounds from bryophytes and inedible fungi. Journal of Pre-clinical and Clinical Research. 7:2, 73-85.

Asakawa Y. Ludwiczuk A. Nagashima F. 2013b. Phytochemical and biological studies of bryophytes. Phytochemistry. 91, 52-80.

Atherton I. Bosanquet S. D. Lawley M. 2010. Mosses and Liverworts of Britain And Ireland - A Field Guide. British Bryological Society. Britain.

Burgess E. Larsen J.L.N. Perry B. 2000. A Cytotoxic sesquiterpene caffeate from the liverwort Bazzania novae-zelandiae. Journal of Natural Products. 63, 537-539.

Chandra S. D. Chandra A. Barh A. Pankaj R. Pandey K. Sharma I. P. 2017. Bryophytes: Hoard of remedies, an ethno-medicinal review. Journal of Traditional and Complementary Medicine. 7:1, 94-98.

Çolak E. Kara R. Ezer T. Çelik G.Y. Elibol B. 2011. Investigation of antimicrobial activity of some Turkish pleurocarpic mosses. African Journal of Biotechnology. 10, 12905-12908.

Dey A. De J.N. 2012. Antioxidative potential of bryophytes: stress tolerance and commercial perspectives: a review. Pharmacologia. 3, 151-159.

Dey A. Mukherjee A. 2015. Therapeutic potential of bryophytes and derived compounds against cancer. Journal of Acute Disease. 4:3, 236-248. 
Komala I.T. Ito F. Nagashima Yagi Y. Asakawa Y. 2010. Cytotoxic, radical scavenging and antimicrobial activities of sesquiterpenoids from the Tahitian liverwort Mastigophora diclados (Brid.) Nees (Mastigophoraceae). Jornal of Natural Medicines. 64, 417-422.

Perry N. B. Foster L.M. Lorimer S.D. May B.C. Weavers R.T. 1996. Isoprenyl phenyl ethers from liverworts of the genus Trichocolea: cytotoxic activity, structural corrections and synthesis. Jornal of Natural Medicines. 59, 729-733.

Rencüzogulları E. İla H.B. Kayraldiz A. Diler S. B. Yavuz A. Arslan M. Kaya F.F. Topaktas M. 2006. The Mutagenic and Antimutagenic Effects of Ecballium elaterium Fruit Juice in Human Peripheral Lymphocytes. Russian Journal of Genetics. 42:6, 623-627.

Saxena D. Harinder K. 2004. Uses of Bryophytes. Resonance. 9:6, 56-65.

Suhalka D. 2016. Eco-Friendly Management of Maize Pathogen Thruogh Bryophyte Extract. Journal of Global Pharma Technology. 8:1, 1-4.

Toyota M. Saito T. Asakawa Y. 1999. The Absolute Configuration of Eudesmanetype Sesquiterpenoids Found in the Japanese Liverwort Chiloscyphus polyanthus. Phytochemistry. 51, 913-920.

Xie C.F. Sun B. Guo D.X. Gao J. Qu J.B. Lou H. X. 2011. Terpenoids from the Chinese Liverwort Chiloscyphus polyanthus. Helvetica Chimica Acta. 94: 3, 534-538.

Yağlıoğlu Ş.E. Abay G. Demirtas İ. Yağlıoğlu Ş.A. 2017. Phytochemical screening, antiproliferative and cytotoxic activities of the mosses Rhytidiadelphus triquetrus (Hedw.) Warnst. and Tortella tortuosa (Hedw.) Limpr. Anatolian Bryology 3:1, 31-42. 